\title{
Preovulatory Changes in Morphology of Rabbit Ovarian Follicles
}

\author{
Takahide MORI, Akira TAKENAKA, Yoshinobu YOSHIDA*, \\ Akira SUZUKI, Yasuhiko FUJITA and Toshio NISHIMURA
}

\author{
Department of Obstetrics and Gynecology, Kyoto University School of \\ Medicine, Sakyo-ku, Kyoto 606 and *Department of Obstetrics and \\ Gynecology, Shiga University of Medical Science, Ohtsu 520-21, Japan
}

\begin{abstract}
Synopsis
To examine timed changes in the morphology of theca interna and granulosa cells of rabbit preovulatory follicles, mature female rabbits were injected with 100 IU per $\mathrm{kg}$ of human chorionic gonadotropin (hCG) and follicles larger than $1 \mathrm{mn}$ in diameter were excised for light and electron microscopic studies before and 3, 6, 9 and $12 \mathrm{hr}$ after hCG injection. Spindle-shaped theca interna cells had been transformed into rounded cells with pronounced hypertrophy within $9 \mathrm{hr}$ after hCG injection, and degenerative changes in cellular appearance with reduction in cellular density became apparent $12 \mathrm{hr}$ after hCG administration. Electron micrographs of thecal cells showed that the maximum proliferation of large mitochondria and the full development of smooth endoplasmic reticulum (sER) had occurred by $6 \mathrm{hr}$ after hCG injection, while by $12 \mathrm{hr}$ after hCG administration abundant lipid droplets had accumulated and sER had decreased. These morphological changes in the theca interna cells indicate an activated endocrine function in the earlier stage followed by diminution in steroidogenesis in the later stage of the preovulatory interval. Although no appreciable changes was noted in granulosa cell histology in the first $6 \mathrm{hr}$ after hCG injection, luteinizing changes proceeded $9 \mathrm{hr}$ or more after hCG administration, as evidenced by the enlargement of cytoplasmic volume. A series of cytoplasmic modifications of granulosa cells leading to the formation of the fine structures characteristic of steroid-producing cells developed gradually in the earlier stage and rapidly in the final stage prior to ovulation, indicating differentiation of granulosa cells into lutein cells. It is concluded that the major cellular site of steroid biosynthesis in ovulating rabbit follicles may shift from degenerating thecal cells to luteinizing granulosa cells in the course of the preovulatory process.
\end{abstract}

It has recently been reported that marked quantitative as well as qualitative changes in steroid biosynthesis in vitro occur in rabbit (Mills and Savard, 1973; Suzuki et al., 1977) and human (Suzuki, et al., 1976; Mori et al., 1978) follicles undergoing ovulation. These functional changes may be associated with cytological and structural alterations in mature follicles following exposure to ovulatory stimulations.

Although preovulatory luteinization of

Received September 4, 1978. granulosa cells of rabbit (Blanchette, 1966), rat (Bjoerkman, 1962), mouse (Byskov, 1969), pig (Bjersing, 1967), cow (Priedkalns and Weber, 1968) and human (Delforge et al., 1972; Yoshida, 1976) has been documented by light and electron microscopic studies, morphological changes in follicles before ovulation are too poorly understood to explain the timed changes in steroidogenic function in the course of ovulation. The present investigation was performed to examine the steroid-producing cells of rabbit ovulating follicles histologically and ultra- 
structurally, and to find out, if possible, the relationship between the functional and morphological events that take place in preovulatory follicles.

\section{Materials and Methods}

Mature virgin female albino rabbits weighing 2.5 to $3.0 \mathrm{~kg}$ were kept in individual cages in an airconditioned animal house at $24^{\circ} \mathrm{C}$ and were fed with artificial nutrients (Oriental Yeast Co. Ltd., Osaka) and water ad libitum. One hundred IU per $\mathrm{kg}$ of human chorionic gonadotropin (hCG) was introduced into animals via the auricular vein. No hCG was injected into control animals. Animals were sacrified before and 3, 6, 9 and $12 \mathrm{hr}$ after hCG injection. The time intervals were chosen to cover the entire process of ovulation in rabbit ovaries after the ovulatory stimulus (Harper, 1961).

Bilateral ovaries were removed from the animals under pentobarbital anesthesia. Several preovulatory follicles of over $1 \mathrm{~mm}$ in diameter, which were readily recognizable as reddish protrusions from the ovarian surface, were dissected out with surrounding tissues. The specimens were immersed in cold $6.25 \%$ glutaraldehyde solution in $0.1 \mathrm{M}$ cacodylate buffer, $\mathrm{pH} 7.4$, containing $8 \%(\mathrm{~W} / \mathrm{V})$ sucrose, for $2 \mathrm{hr}$. The fixed tissues were trimmed to approximately $1 \mathrm{~mm}^{3}$ and postfixed with a chilled $1 \%(\mathrm{~W} / \mathrm{V})$ solution of osmium tetraoxide for another $2 \mathrm{hr}$. The postfixed tissues were stained en bloc in a saturated uranyl acetate solution, dehydrated in a series of ethanol solutions of ascending concentration and embedded in Epon 812. Ultrathin sections were prepared with a glass knife on a Sorvall MT-2B "Porter-Blum" ultramicrotome and stained with a lead solution. A Hitachi HU-11D electron microscope was used for ultrastructural observations at $75 \mathrm{kv}$. Thick sections $(0.5-1 \mu \mathrm{m})$ were likewise prepared and stained with $0.2 \%(\mathrm{~W} / \mathrm{V})$ toluidine blue for light microscopy.

\section{Results}

\section{Follicles before $h C G$ injection}

The theca interna of mature follicles before administration of hCG consisted of two to three layers of spindle-shaped cytoplasmrich cells interspersed with a few fibroblasts and capillary vessels. The cells were oriented parallel to the basement membrane of the granulosa cell layer.
The granulosa layer comprised a compact arrangement of relatively small cuboidal cells with ovoid nuclei and cytoplasm. The basal granulosa cells were columnar, and some were attached to the basal lamina by cytoplasmic prolongations (Plate 1, Fig. 1), resembling pseudostratified epithelium (Lipner and Cross, 1968). Ultrastructurally, theca interna cells possessed many characteristics of steroid-secreting cells (Chrstensen and Gillim, 1969; Yoshida, 1976). A moderate number of large round or oval mitochondria with tubular cristae were scattered throughout the cytoplasm. Smooth endoplasmic reticulum (sER) predominated over rough endoplasmic reticulm (rER), both of which were small vesicular in shape. Numerous free ribosomes were dispersed diffusely within the cytoplasmic matrix. Some lipid droplets were seen (Plate 2, Fig. 1). On the other hand, granulosa cells presented an ultrastructural picture commonly seen in protein-synthesizing cells (Bjoerkman, 1962; Christensen and Gillim, 1969; Yoshida, 1976). An abundance of free ribosomes distributed within the cell. In contrast to the poorly differentiated sER, the rER was moderately developed and arranged in a small vesicular or in inadequate lamellar fashion. A number of small rod-shaped mitochondria with lamellar cristae were distributed evenly within the cytoplasm. The small Golgi complex was located adjacent to the nucleus, which appeared irregular in shape with one to two nucleoli. A few lipid droplets were also seen (Plate 2, Fig. 2).

\section{Follicles 3 hours after hCG injection}

Most of the interna cells became somewhat rounded and the capillaries dilated with hypermia. Granulosa cells were not appreciably different histologically from those found before hCG injection (Plate 1, Fig. 2). Electron micrographs of theca interna cells revealed the proliferation of large mitochondria and the considerable 

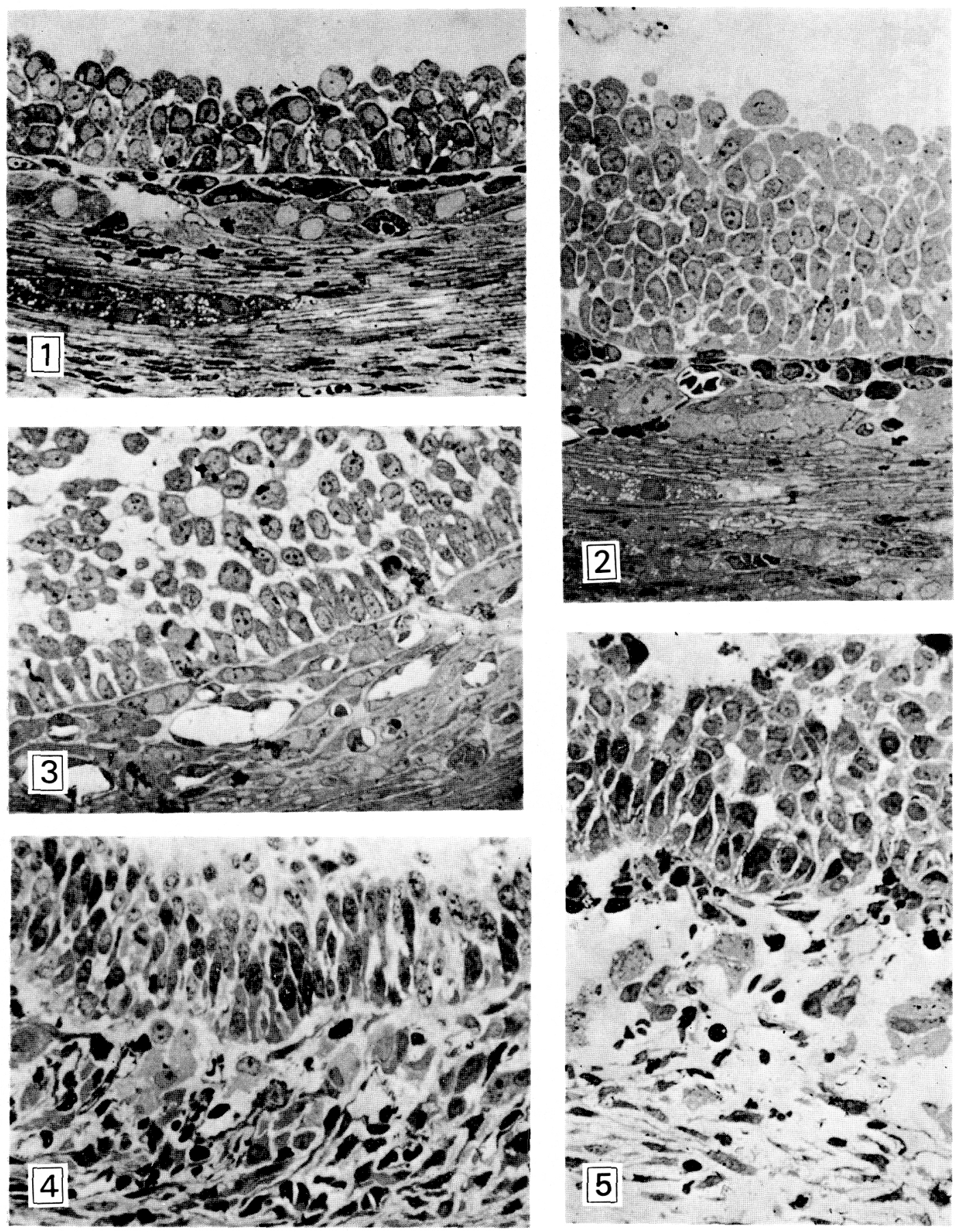

Plate 1. A series of photomicrographs of preovulatory rabbit follicles taken at 0 (Fig. 1), 3 (Fig. 2), 6 (Fig. 3), 9 (Fig. 4) and 12 (Fig. 5) hr after hCG injection. Semi-ultrathin sections prepared from Epon-embedded materials were stained with toluidin blue. $\times 700$. 

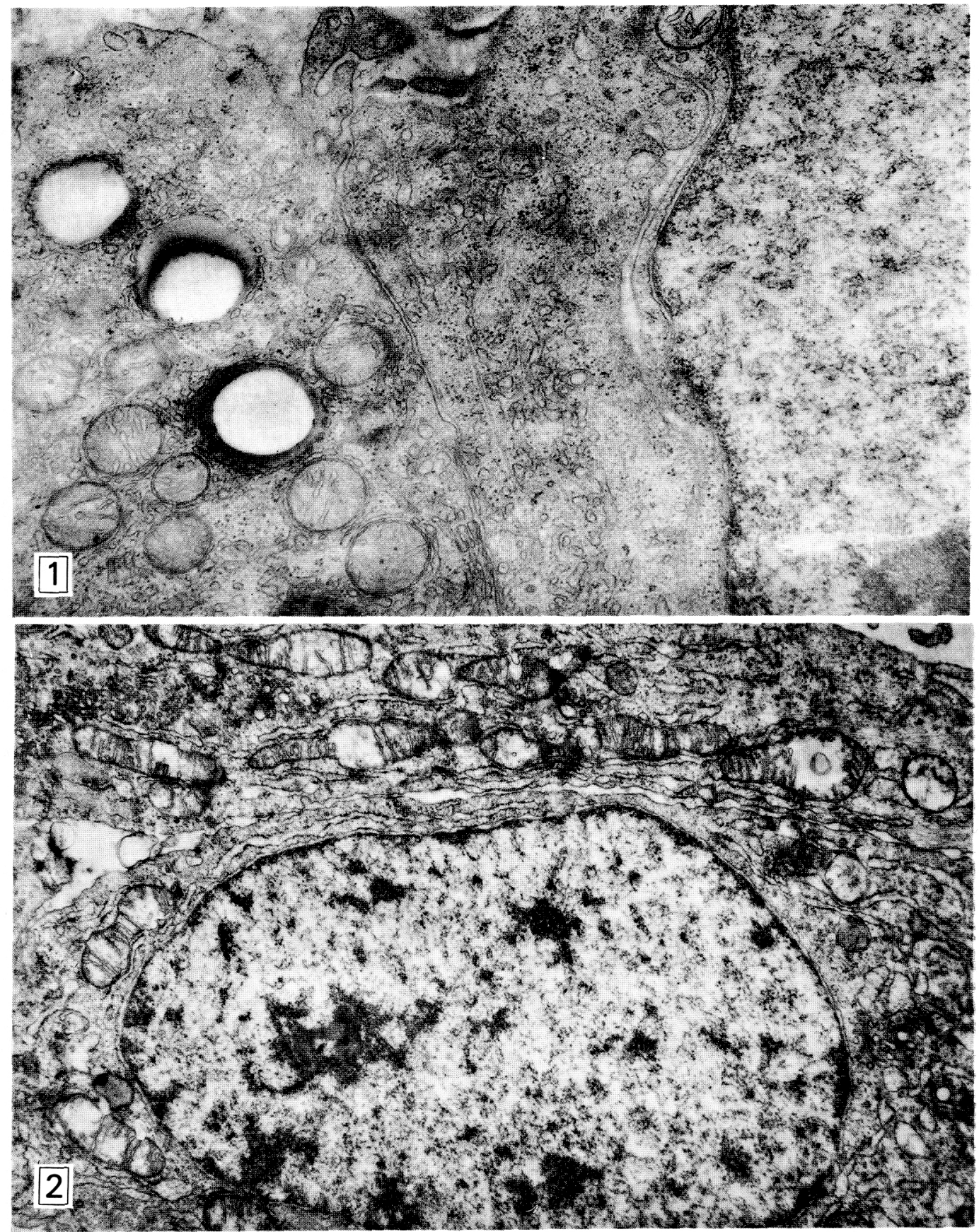

Plate 2. Fig. 1. An electron-micrograph of the theca interna cell of the mature follicle before hCG injection. The cytoplasm possesses characteristic ultrastructures typical of steroid-secreting cells. $\times 19,500$

Fig. 2. An electron-micrograph of the granulosa cells of the mature follicle before hCG injection. The poor cytoplasm represents an ultrastructural picture common to protein-synthesizing cells. $\times 10,000$. 

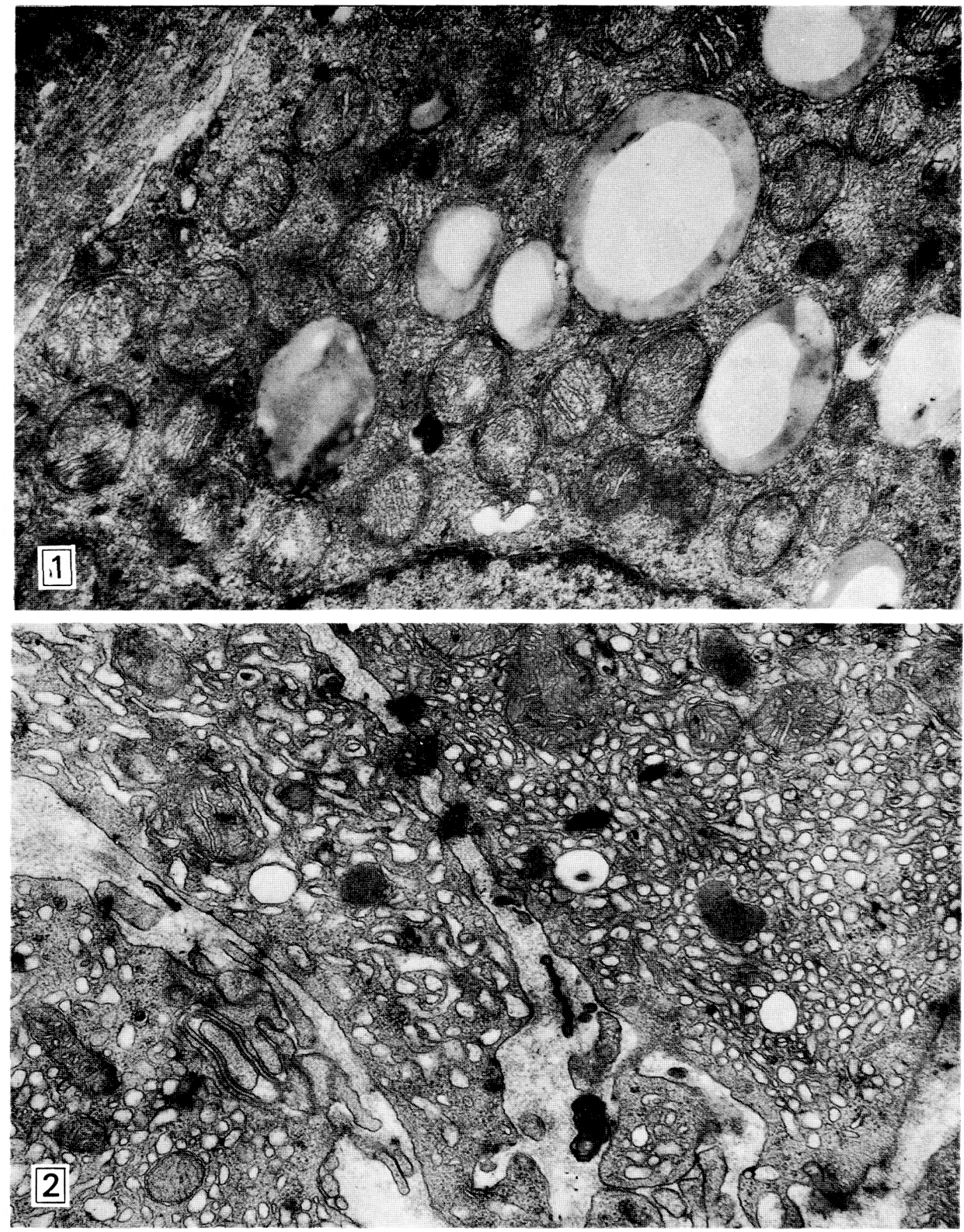

Plate 3. Fig. 1. An electron-micrograph of the theca interna cell of the preovulatory follicle $3 \mathrm{hr}$ after hCG injection. Large mitochondria with tubular cristae and sER were fully developed. $\times 17,500$.

Fig. 2. An electron-micrograph of the theca interna cell of the preovulatory follicle $9 \mathrm{hr}$ after hCG injection. Mitochondria tending to enlarge and vesicular sER with lamellar or annular orientation were seen in the peripheral region of the cytoplasm. $\times 18,750$. 
development of sER with occasional formation of anatomosing plexuses (Plate 3, Fig. 1). The organelles and inclusions of granulosa cells remained virtually except for a slight increase in the number of vesicular elements.

\section{Follicles 6 hours after hCG injection}

Moderate histological changes were noted in follicles at this time. The theca interna became highly vascularized and edematous with cells loosely apposed. Granulosa cells tended to be dispersed, resulting in distension of intercellular spaces, but not significantly changed in cellular appearance. The orientation of parietal granulosa cells became irregular, but the basement membrane remaind well preserved (Plate 1, Fig. 3). Ultrastructurally theca interna cells were found to contain the greatest number of large mitochondria seen at any stage of the preovulatory, in a tight arrangement with fully developed sER in the cytoplasm. Annular arrangements of sER were sometimes seen in the peripheral region of the cytoplasm. Granulosa cells showed no significant ultrastructural alteration from the previous stage.

\section{Follicles 9 hours after hCG injection}

Marked histological changes became manifest in the follicle structure at this time. Although varying in degree among individual cells, theca interna cells were clearly hypertrophied. Intercellular spaces were markedly distended and the cells were often oriented perpendicular than parallel to the basement membrane, which was irregular and with bundles of thecal cells protruding into the granulosa layer in portions. Granulosa cells were elongated, contained an increased amount of cytoplasm, and lay perpendicular to the basal lamina (Plate 1, Fig. 4). On electron microscopic study, mitochondria of theca interna cells tended to increase in size and the sER appeared vesicular, sometimes having la- mellar orientation in the peripheral region of the cytoplasm (Plate 3, Fig. 2). The Golgi apparatus of glanulosa cells became enlarged and a number of lipid droplets of 0.5 to $2 \mu$ in diameter appeared (Plate 4, Fig. 1). Small vesicular sER was cleary recognized in some granulosa cells but not in most of them. Glycogen granules appeared transiently in some granulosa cells between 9 and $12 \mathrm{hr}$ after hCG administration.

\section{Follicles 12 hours after hCG injection}

The theca interna layer was obviously reduced in cellular density and was composed mostly of degenerating cells with contracted or angular cell borders, together with an increased number of lipid droplets. Intercellular spaces were extremely distended. The basal lamina was indistinct, being discernible only where the structure was lined by granulosa cells. The membrana granulosa consisted of enlarged round cells (Plate 1, Fig. 5). The ultrastructural apearance of theca interna cells was characterized by the accumulation of a large number of lipid droplets and the decrease in the number of sER. In granulosa cells the mitochondria were enlarged, with tubular cristae typical of those in steroidsecreting cells. The Golgi complex was enlarged and a number of vesicular or tubular sER were identified in most of granulosa cells. Structural continuity of the sER with the rER was occasionally observed (Plate 4, Fig. 2).

\section{Discussion}

Because of the nature of reflex ovulators in rabbits, a timed study on the expected synchronized events that happen in the preovulatory process makes it possible to examine the sequential changes in morphology and function of ovulating follicles in response to ovulatory stimuli. The present 

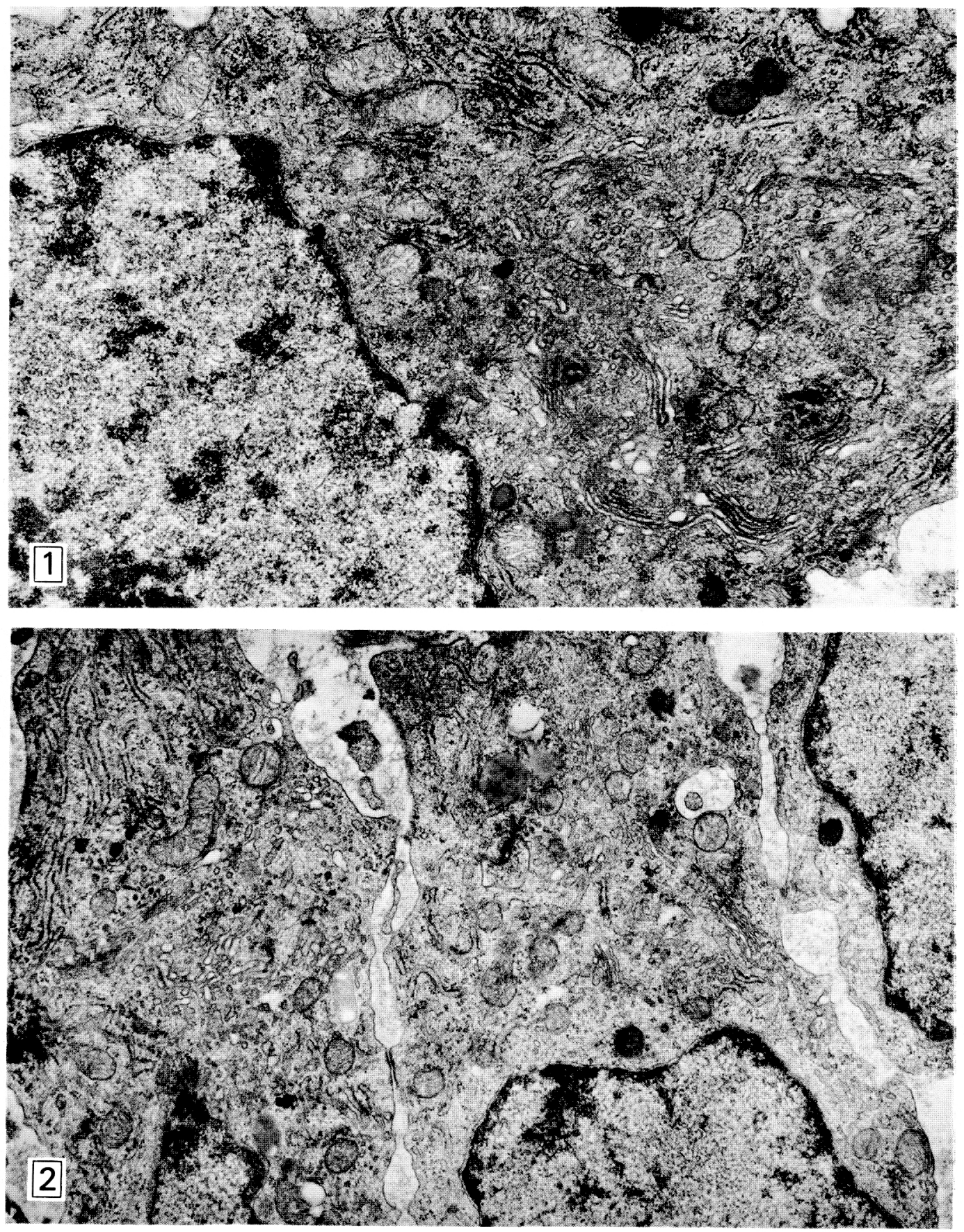

Plate 4. Fig. 1. An electron-micrograph of the granulosa cell of the preovulatory follicle $9 \mathrm{hr}$ after hCG injection. The enlarged Golgi complex and a number of lipid droplets were noted. $\times 17,500$.

Fig. 2. An electron-micrograph of the granulosa cell of the preovulatory follicle $12 \mathrm{hr}$ after hCG injection. Enlarged mitochondria with tubular cristae and vesicular sER were clearly increased in number within the enriched cytoplasm. $\times 17,500$. 
investigation has disclosed marked changes in the morphology of the two types of steroid-secreting cells of the follicle. Advancement of cytological architecture associated with steroid formation followed by degenerative changes was observed in theca interna cells, while progressive development of luteinization prior to follicle rupture was noted in granulosa cells. During the same interval, remarkable changes in steroidogenic function have been reported to occur, which are characterized by an initial rise and a subsequent fall around the time of ovulation (Mills and Savards, 1973; Suznki et al., 1977). The observed events in the morphology of follicle cells in the present study may offer substantial evidence for the interpretation of biochemical changes within preovulatory follicles.

Follicles from estrus rabbit before ovulatory stimuli are cabable of synthesizing an array of steroids covering progestins, androgens and estrogens in vitro (Mills and Savard, 1972). Of the two types of cells observed in follicles before hCG injection, theca interna cells possessed all the ultrastructural features characteristic of steroid-secreting cells (Christensen and Gillim, 1969; Yoshida, 1976), while glanulosa cells showed fine-structures similar to those of protein-retaining cells (Birbeck and Mercer, 1961; Bjoerkman, 1962; Yoshida, 1976). It is therefore likely that the major site of steroid biosynthesis in control follicles is the theca interna cell. However, granulosa cells may contribute to aromatizing androgen to estrogen, as reported in rat granulosa cell in vitro (Dorrington et al., 1975), since potent aromatase activity is present in the human placenta (Diczfalusy and Mancuso, 1969) devoid of typical ultrastructures of steroid-secreting cells (Yoshida, 1975).

Following an acute rise in steroidogenic function in response to the ovulatory stimulus of mating or hCG injection, the enhanced synthetic activity of the stimulated follicles is reported to continue for about $6 \mathrm{hr}$, as evidenced by in vitro experiments Mills and Savard, 1973; Suzuki et al., 1977) and by high concentrations of steroids in the follicular fluid (Younglai, 1972; Patwardhan and Lantheir, 1976). The present study showed that the fine-structures relevant to steroidogenic function in theca interna cells were fully developed $6 \mathrm{hr}$ after hCG injection, that is, the maximum proliferation of large mitochondria and full development of sER were seen at this time. These cytological changes may be a reflection of the activated endocrine function of the cells. On the other hand, a slight but significant increase in number of vesicular elements with a concomitant decrease in the amount of free ribosome was found in the cytoplasmic matrix of granulosa cells between 3 and $6 \mathrm{hr}$ after hCG injection (Bjoerkman, 1962; Byskov, 1969); a similar response is reported on rabbit granulosa cells as early as $2 \mathrm{hr}$ after mating (Blanchette, 1966). Although the findings could be regarded as a complex of early signs of luteinization, it is hard to estimate to what extent granulosa cells are involved in the steroidogenic function of the follicle in the earlier stage of the preovulatory interval. However, the pronounced capillary reactions in this stage, which seem to be a morphological reflection of accelerated hemodynamics in sheep ovaries during the ovulatory phase (Moor et al 1975) or in rabbit ovaries after hCG stimulation (Blasco et al., 1975), may contribute to the functional activities of steroidproducing cells by transportation of precursor substances.

In the later stage of the preovulatory interval, a gradual decline in quantitative capacity of steroid biosynthesis has been found both in vitro (Milss and Savard, 1973; Suzuki et al., 1977) and in vivo (Younglai, 1972; Patwardhan and Lantheier, 1976). The hypertrophied appearance of theca interna cells observed $9 \mathrm{hr}$ 
after hCG is quite similar to those described for rat preovulatory follicles by the term thecal luteinization (Hori et al., 1970) or for human atretic follicles by the term luteinzing thecal cells (Mori, 1969; Mori, 1976). This histology may be reflected by an exaggeration in enlargement of mitocondrial and vesicular elements on the electron micrograph (Bjoerkman, 1962). However, $12 \mathrm{hr}$ after hCG administration were seen apparent degenerative changes, accompanied by an abrupt reducton in the number of the cells per unit area, as has been encounted in the human follicle just prior to ovulation (Mori et al., 1978). The degenerative chages were reinforced ultrastructurally by an accumulation of abundant lipid droplets and a decrease of sER. The accumulation of the intracellular inclusions may signify a low turn over rates of steroids with much storage of precursors or products. In addition, the progressive expansion of edema in thecal cells in the later stage, as pointed out in a previous report (Bjersing and Cajander, 1974), could be unfavorable for the cells in terms of substrate availability and cellular metabolism. These cellular and environmental conditions would account for the decline in the endocrine activity of follicles in the later stage of the preovulatory interval.

An increase in cytoplasmic volume of granulosa cells $12 \mathrm{hr}$ after hCG injection seems equivalent to a histological index of preovulatory luteinization (Delforge et al., 1972). The series of cytoplasmic modifications leading to the aquisition of ultrastructural characteristics of steroid-secreting cells by granulosa cells in the final stage before follicle rupture may indicate that differentiation of the cells into lutein cells has begun prior to ovulation but is not complete. It is likely that the primary site of steroid biosynthesis in ovulating follicles shifts from degenerating theca cells to luteinizing granulosa cells in the final stage prior to rupture. The terminal fall in steroidogenic activity of the follicle would represent the transient functional depression of degenerating theca interna cells and functional immaturity of luteinizing granulosa cells.

This work was supported by a grant from The Ministry of Health and Welfare for research on handicapped children and in part by a grant-in-aid from The Ministry of Education, Japan (No. 248300).

\section{References}

Birbeck, M. S. C. and E. H. Mercer (1961). Nature $189,558$.

Bjersing, L. and S. Cajander (1974). Cell. Tissue. Res. 149, 287.

Bjoerkman, N. (1962). Acta Anat. 51, 125.

Blanchette, E. L. (1966). J. Cell. Biol. 31, 501.

Blasco, L., C-H. Wu, G. L. Flickinger, D. Pearlmutter and G. Mikhail (1975). Biol. Reprod. 13, 581.

Byskov, A. G. S. (1969). Z. Zellforsch. 100, 285.

Christensen, A. K. and S. W. Gillim. The Gonads (edited by K. W. McKerns). Appleton-CenturyCrofts, New York, p. 415 (1969).

Delforge, J. P., K. Thomas, F. Roux, J. C. de Siqueira and J. Ferin (1972). Fertil. Steril. 23, 1.

Diczfalusy, E. and S. Mancuso Foetus and Placenta (edited by A. Klopper and E. Diczfalusy). Blackwell Scientific Publications, Oxford, p. 191 (1969).

Dorrington, J. H., Y. S. Moon and D. T. Armstrong (1975). Endocrinology 97, 1328.

Hori, T., M. Ide, G. Kato and T. Miyake (1970). Endocrinol. Japon. 67, 489.

Harper, M. J. K. (1961). J. Endocrinol. 22, 147.

Lipner, H. and N. Cross (1968). Endocrinology 82, 638 ,

Mills, T. M. and K. Savard (1972). Steroids 29, 247.

Mills, T. M. and K. Savard (1973). Endocrinology 92, 788.

Moor, R. M., M. F. Hay and R. F. Seamark (1975). J. Reprod. Fert. 45, 595.

Mori, T. (1969). Acta Obstet. Gynecol. Japon. 16, 156.

Mori, T. (1976). Endocrinol. Japon. 23, 365.

Mori, T., Y. Fujita, A. Suzuki, Y. Kinoshita, T. Nishimura and A. Kambegawa (1978). J. Clin. Endocrinol. Metab. 47, 955.

Patwardhan, V. V. and A. Lanthier (1976). Acta Endocrinol. 82, 792.

Priedkalns, J. and A. F. Weber (1968). Z. Zellforsch. 91, 554. 
Suzuki, A., T. Mori, Y. Fujita, M. Murata, M. Kitagawa and T. Nishimura (1976). Acta Obstet. Gynec. Jap. 23, 207.

Suzuki, A., T. Mori and T. Nishimura (1977). Endocrinol. Japon. 24, 129.

Yoshida, Y. (1975). Acta Obstet. Gynecol. Japon. 22, 205.

Yoshida, Y. Gendai Sanka Fujinka Taikei (Handbook of Modern Obstetrics and Gynecology), The supplementary issue for the year of 1976. Nakayama Shoten, Tokyo, p. 3 (1976). (In Japanese)

Younglai, E. V. (1972). J. Reprod. Fert. 30, 157. 